\title{
Thyroid Function Tests in the Newborn
}

\author{
M. A. CHADD, O. P. GRAY, and D. F. DAVIES \\ From the Department of Child Health, Welsh National School of Medicine, and \\ Department of Pathology, Glangwili, Carmarthen
}

\begin{abstract}
Chadd, M. A., Gray, O. P., and Davies, D. F. (1970). Archives of Disease in Childhood, 45, 374. Thyroid function tests in the newborn. The 131I triiodothyronine $\left(\mathrm{T}_{3}\right)$ resin uptake test reflects thyroid function more closely than other acceptable tests currently available.

The $\mathrm{T}_{3}$ uptake and protein-bound iodine (PBI) level were estimated in 20 premature and 20 full-term infants at birth and at the end of 1 week.

The full-term infant has normal adult values, whereas the premature baby has results extending into the hyperthyroid range at birth, but these fall to within normal limits at 1 week.
\end{abstract}

There are few studies of thyroid function in the newborn and neonatal period of infants born earlier than the 37th week of gestation. Proteinbound iodine (PBI) levels are similar to those obtained for full-term infants (Danowski et al., 1950). The radioactive iodine (131I) uptake test has limited value because of the risk from irradiation.

The in vitro test of radioactive ${ }^{131}$ I-labelled triiodothyronine uptake using red blood cells was introduced by Hamolsky, Stein, and Freedberg (1957). A similar test was used by later workers using a resin substituted for red blood cells (Nava and De Groot, 1962; Godden and Garnett, 1964). This test measures the degree of saturation of thyroid-binding globulin, whereas the PBI test measures the protein-bound thyroid hormones thyroxine, tri-iodothyronine, and iodotyrosine.

Comparison of this test with the conventional PBI test in the neonatal period was made by Evans (1966), using paired maternal and cord blood samples. This work included very few premature infants. We have therefore undertaken a study comparing these two tests in premature and full-term infants.

\section{Materials and Methods}

Blood was obtained from the umbilical cord after delivery of placenta or from a peripheral vein within 12 hours of birth for estimation of values and triiodothyronine resin uptake values from 20 full-term infants and 20 low birthweight infants (less than 37 weeks' gestation).

Received 8 September 1969.
The tests were repeated on the 8 th day of life. Plasma-bound iodine was estimated by Auto-analyser The ${ }^{131}$ I tri-iodothyronine $\left(T_{3}\right)$ resin uptake test was estimated after the method of Gimlette (1967). The. $\mathrm{T}_{3}$ adult euthyroid range is for this laboratory 70-140\%.

The $\mathrm{T}_{3}$ test can now be performed on as little as $0.1 \mathrm{ml}$. plasma.

\section{Results}

The PBI levels in both the full-term and premature infants confirm the known high mean and $\frac{3}{5}$ wide ranges of cord blood, with even higher levels at the end of the first week (Table). However, $T_{3}$ resin uptake is normal for the full-term infants both at birth and at the end of the first week. -5 The premature infants' cord results show a high 3 . mean with a very wide range at birth, but by the end of the first week these results also show a normal mean and range.

The mean cord blood PBI in both term and premature infants is at the upper limit of adulto normal euthyroid values $(3.5 \mu \mathrm{g} .-8 \cdot 0 \mu \mathrm{g} . / 100 \mathrm{ml}$. plasma) (Perry, Hodgman, and Starr, 1965; Rose, o Russell, and Starr, 1963).

Both full-term (Danowski et al., 1950) and premature infants (Chadd, Davies, and Gray, 1968) showed a rise of the PBI values, above the upper limit of adult euthyroid normal, $8 \mu \mathrm{g} . / 100 \mathrm{ml}$. during the first week of life. Values of 10-14 $\mu \mathrm{g} . / 100 \mathrm{ml}$. were frequently obtained between 48 hours and 8 days of life by Chadd et al. (1968) in premature infants. These values gradually fell $\mathbb{D}$ over the next 2-3 months. 
TABLE

Plasma Protein-bound Iodine Levels and $T_{3}$ Uptake Test in Newborn Infants

\begin{tabular}{|c|c|c|c|c|c|c|}
\hline & Birthweight (kg.) & Gestation (wk.) & $\begin{array}{l}\text { Protein-bound } \\
\text { Iodine at Birth } \\
(\mu \mathrm{g} . / 100 \mathrm{ml} .)\end{array}$ & $\begin{array}{c}\mathrm{T}_{3} \text { Uptake } \\
\text { at Birth } \\
(\%)\end{array}$ & $\begin{array}{l}\text { Protein-bound } \\
\text { Iodine at } 8 \text { Days } \\
(\mu \mathrm{g} .1100 \mathrm{ml} .)\end{array}$ & $\begin{array}{c}T_{3} \text { Uptake } \\
\text { at } 8 \text { Days } \\
(\%)\end{array}$ \\
\hline $\begin{array}{l}20 \text { Premature } \\
\text { Mean } \\
\text { Range } \\
1 \text { SD } \\
20 \text { Full-term } \\
\text { Mean } \\
\text { Range } \\
1 \text { SD }\end{array}$ & $\begin{array}{l}2 \cdot 0 \\
1 \cdot 0-3 \cdot 9 \star \\
3 \cdot 0 \\
2 \cdot 5-3 \cdot 9\end{array}$ & $\begin{array}{l}33 \cdot 6 \\
26-35 \\
\\
39 \\
36-41\end{array}$ & $\begin{array}{l}7 \cdot 8 \\
5 \cdot 4-11 \cdot 2 \\
1 \cdot 83 \\
9 \cdot 5 \\
6 \cdot 1-13 \cdot 8 \\
2 \cdot 67\end{array}$ & $\begin{array}{l}138 \\
62-227 \\
34 \cdot 79 \\
\\
98 \\
70-160 \\
32 \cdot 8\end{array}$ & $\begin{array}{l}8 \cdot 7 \\
5 \cdot 8-12 \cdot 8 \\
1 \cdot 70 \\
\\
9 \cdot 8 \\
8 \cdot 8-14 \cdot 4 \\
3 \cdot 16\end{array}$ & $\begin{array}{l}94 \\
69-140 \\
21 \cdot 76 \\
\\
100 \\
71-157 \\
21 \cdot 26\end{array}$ \\
\hline
\end{tabular}

^N.B. 1 premature diabetic infant included, but birthweight $3.9 \mathrm{~kg}$., gestation-36 weeks.

The radioactive iodine (131I) test has been used to assess thyroid function in the neonatal period in both full-term infants (Van Middlesworth, 1954) and in premature infants (Martmer et al., 1956). Their results confirm the impression of transient hyperthyroidism in the neonatal period. This test is not widely used because of the risks of irradiation.

The raised PBI in the newborn may be due to oestrogen binding and falsely suggests increased thyroid activity. $T_{3}$ resin uptake test, however, measures the saturation of thyroid activity. Evans (1966) found in normal newborn infants mean cord blood PBI of $7.5 \mu \mathrm{g} . / 100 \mathrm{ml}$., and $81 \%$ for the $T_{3}$ resin uptake test.

In term infants the $T_{3}$ resin uptake is well within the adult normal euthyroid range for our laboratory (70-140\%), and is unchanged at the end of the first week of life.

The premature newborn infant, however, shows a raised $T_{3}$ uptake test at birth, which falls to within the normal euthyroid adult range (70-140\%) by the end of the first week. This suggests that at birth the premature infant has a true increase in thyroid hormones.

We wish to acknowledge the technical assistance of Mr. D. D. Jones and the considerable secretarial help of Miss Anne Mayled. This work was carried out while one of us (M.A.C.) was in receipt of a Children's Research Fund Grant.

\section{REFERENCES}

Chadd, M. A., Davies, D. F., and Gray, O. P. (1968). Proteinbound iodine in premature infants. Archives of Disease in Childhood, 43, 217.

Danowski, T. S., Gow, R. C., Mateer, F. M., Everhart, W. C., Johnston, S. Y., and Greenman, J. H. (1950). Increase in serum thyroxin during uncomplicated pregnancy. Proceedings of the Society for Experimental Biology and Medicine, 74, 323.

Evans, N. A. P. (1966). Comparison of the in vitro I131 triiodothyronine resin uptake test and the protein bound iodine in the parturient and the newborn infant (cord blood). Biologia Neonatorum, 10, 119.

Gimlette, T. M. D. (1967). Use of Sephadex column chromatography in the assessment of thyroid status. Fournal of Clinical Pathology, 20, 170.

Godden, J. D., and Garnett, E. S. (1964). The I131 tri-iodothyronine-resin uptake test. Fournal of Endocrinology, 29, 167.

Hamolsky, M. W., Stein, M., and Freedberg, A. S. (1957). The thyroid hormone-plasma protein complex in man. II. A new in vitro method for study of 'uptake' of labelled hormonal components by human erythrocytes. Fournal of Clinical Endocrinology and Metabolism, 17, 33.

Martmer, E. E., Corrigan, K. E., Charbeneau, H. P., and Sosin, A. (1956). A study of the uptake of iodine (I-131) by the thyroid of premature infants. Pediatrics, 17, 503.

Nava, M., and De Groot, L. J. (1962). Resin uptake of $\mathbf{I}^{131}$ labeled triiodothyronine as a test of thyroid function. New England fournal of Medicine, 266, 1307.

Perry, R. E., Hodgman, J. E., and Starr, P. (1965). Maternal, cord and serial venous blood: protein-bound iodine, thyroid-binding globulin, thyroid-binding albumin, and prealbumin values in premature infants. Pediatrics, 35, 759.

Rose, H., Russell, K. P., and Starr, P. (1963). Serum proteinbound iodine of mothers and infants at delivery in premature and term pregnancies. American Fournal of Obstetrics and Gynecology, 86, 767.

Van Middlesworth, L. (1954). Radioactive iodine uptake of normal newborn infants. American Fournal of Diseases of Children, 88, 439.

Correspondence to Dr. M. A. Chadd, c/o Department of Paediatric Research, Cardiff Maternity Hospital, Glossop Terrace, Cardiff CF2 1XF. 